\title{
BEHOLD!!! THE PROTONG - POTOP I MAŁPOLUDY, CZYLI TEODYCEA STANISŁAWA SZUKALSKIEGO
}

\author{
Joanna Klara TESKE (Lublin)
}

\section{Wprowadzenie}

Album Behold!!! The Protong (1980, w polskim tłumaczeniu Oto Macimowa! ${ }^{1}$ ) Stanisława Szukalskiego (1893-1987) to starannie opracowany graficznie, bogato ilustrowany wykład Zermatyzmu ${ }^{2}$, nad którym artysta podjął pracę w latach 40. ubiegłego stulecia ${ }^{3}$, by kontynuować ją przez blisko pół wieku, do ostatnich dni swego życia ${ }^{4}$. Zermatyzm był, w zamierzeniu autora, teorią naukową obejmującą różne zjawiska z dziedziny m.in. astronomii, geografii, geologii, antropologii, językoznawstwa czy historii, po raz pierwszy trafnie odczytującą ich faktyczne znaczenie. Ponieważ cała teoria liczyła 39 tomów ${ }^{5}$ niezwykle obszernych badań i rozważań, album, który po-

${ }^{1}$ S. Szukalski, Behold!!! The Protong, San Francisco 2000. Wszystkie cytaty według tego wydania (dalej: BP i numer strony). Oryginalne wydanie zatytułowane Troughful of Pearls/ Behold!!! The Protong pochodzi z 1980 roku. Polski przekład albumu dotychczas nie ukazał się.

${ }^{2}$ Podane przez autora objaśnienie terminu ,zermatyzm” przytaczam, w tekście eseju. Warto tu jednocześnie odnotować, że album zawiera także dwa teksty de facto niezwiązane z teorią Zermatyzmu: „,Katyn” or Godeagle and the Predator (Katyń albo Orzeł Boga i drapieżnik, BP, s. 84-86) oraz Society or Public (Społeczeństwo czy publiczność, BP, s. 91-94). Pierwszy tekst dotyczy dwóch pomników zaprojektowanych przez autora, które miały być poświęcone Kopernikowi i ofiarom zbrodni katyńskiej. Drugi przedstawia krytyczny obraz społeczeństwa polskiego oraz publicznej edukacji, jak i poglądy autora na temat patriotyzmu.

${ }^{3}$ Taka informacja znajduje się na okładce albumu; por. także przypis nr 12 .

${ }^{4}$ Jak podaje Lechosław Lameński w monografii poświęconej artyście; zob.: L. Lameński, Stach z Warty Szukalski i Szczep Rogate Serce, Lublin 2007, s. 229. (Rozdział piąty monografii Zermatyzm i Macimowa, czyli rozważania lingwistyczno-antropologiczne Szukalskiego poświecony jest albumowi, s. 229-247).

${ }^{5}$ Lameński podaje 42 tomy, zaznacza przy tym, że zostały spisane opracowanym przez autora pismem (s. 230). W liście do Biblioteki Publicznej w Gidlach, wysłanym niecałe dwa mie- 
wstał z inspiracji przyjaciela i wydawcy artysty, Glenna Bray’a, miał być zaledwie pierwszą, bardzo okrojoną, publiczną prezentacją nowych idei, zapowiedzią właściwej publikacji, do której jednak nigdy nie doszło. Wydaje się, że praca mogła mieć również w założeniu w jakiejś mierze charakter świadectwa: autor nazywa ją „księgą zaprawdę tragiczną, choć pozbawioną łez"6 i pragnie także za jej pomocą pełnić misję, która między innymi jemu przypadła w udziale: „oddać chwałę Ideom, bohaterskim postaciom, które na jakimkolwiek polu prowadzą naprzód ludzki gatunek, oraz historycznym chwilom",

Mający uchodzić za pracę naukową projekt Zermatyzmu Stanisława Szukalskiego, w wersji w jakiej został opublikowany, łatwiej jest jednak zrozumieć jako dzieło sztuki (album zawiera ponad dwieście rysunków ${ }^{8}$ i reprodukcji prac Szukalskiego) ${ }^{9}$, albo objaw zaburzeń psychicznych (w albumie autor poświęca najwięcej uwagi Potopowi i Małpoludom) ${ }^{10}$, albo wreszcie - jak to się nierzadko zdarza — ich połączenie. W poniższym eseju proponuję jednak pominąć wartość stricte estetyczną dzieła i spekulacje na temat stanu psychicznego autora, by przyjrzeć się treściom filozoficznym albumu. Mimo iż teorie Szukalskiego mogą robić wrażenie „wiatrem podszytych” i wzbudzać obawy, że ich autor ,,[z]upełnie utracił poczucie rzeczywistości i żyje w swoim urojonym świecie", jak pisze Stanisław Gliwa ${ }^{11}$, wydaje się, że w tym bogactwie fantazji kryje się pewien spójny i dość racjonalny zamysł i że jest nim próba obrony wartości świata, a w szczególności szlachetności i piękna człowieka oraz istnienia i dobroci Boga, wobec dojmującego poczucia wszechobecności cierpienia i zła.

Przedstawiając tę interpretację albumu, spróbuję najpierw omówić główne założenia teorii Szukalskiego, by następnie skupić się na tezach, które bezpośrednio dotyczą Boga oraz cierpienia i zła. Będzie to zatem próba systematycznego wykładu teorii Zermatyzmu, którą sam autor przedstawia w formie tematycznie uporządkowanych, obszernych, narracyjno-opisowych komentarzy do ilustracji, połączona z opracowaniem wątku teodycei. Tytułem wstępu opiszę jeszcze pokrótce metodę, jaką zastosował Szukalski tworząc swoje dzieło, bo choć metoda ta nie spełnia warunków stawianych metodzie naukowej (brakuje tu przede wszystkim krytycznej oceny stawianych hipotez), to jednak uwaga, jaką autor jej poświęcił, zdaje się wskazywać, że zależało mu na tym, by jego wizja była czymś więcej niż tylko artystyczną fantazją.

siące przed śmiercią z miejscowości Burbank, Szukalski podaje liczbę 64; zob.: Gminna Biblioteka Publiczna w Gidlach, list S. Szukalskiego z 23 marca 1987 roku.

6 ,this really tragic, though tearless book”, $B P$, s. 6 [wszystkie thum. - J. K. T.].

7 ,to glorify ideas, heroic individuals in whatever fields of elevating the human species, and historic moments", $B P$, s. 6.

${ }^{8}$ Według informacji podanej na okładce albumu w sumie na potrzeby teorii Zermatyzmu Szukalski wykonał ponad 40000 ilustracji.

${ }^{9}$ Ten rozdźwięk między zamiarem autora a recepcją dzieła widać także w opinii Lameńskiego, który, omawiając to dokonanie Szukalskiego, odnotowuje, że był to „aspekt tzw. działalności naukowo-badawczej”, ale zestawia je następnie z innymi dziełami sztuki, pisząc, że było to „dzieło nie mające odniesienia w sztuce XX wieku”; L. Lameński, Stach z Warty Szukalski s. 229-230.

${ }^{10} \mathrm{~W}$ zakończeniu swojej monografii poświęconej artyście, Lameński rozważa pokrótce kondycję psychiczną Szukalskiego; cytuje tu m.in. opinie Franciszka Walczowskiego i Macieja Mieziana. Pierwszy z nich pisze o chorobie psychicznej Szukalskiego, drugi, bardziej precyzyjnie, o paranoi (L. Lameński, Stach z Warty Szukalski, s. 434-435), żaden nie jest jednak psychiatrą i opinie te, co oczywiste, nie są wiążące.

${ }^{11}$ Cyt. za: L. Lameński, Stach z Warty Szukalski, s. 435. 


\section{Metoda naukowa Szukalskiego}

Teoria Zermatyzmu opiera się przede wszystkim na interpretacji źródeł ikonograficznych, tj. rozmaitych artefaktów pozostawionych przez człowieka na całym globie, zwłaszcza tych, które powstały u zarania cywilizacji. Bierze też pod uwagę Szukalski obserwacje klimatyczne, astronomiczne (fotografie plam na słońcu czy powierzchni Marsa), zjawiska geologiczne (powiększanie się Sahary, ruch kontynentów) oraz zdarzenia znane z historiografii (potop, koronacja Karola Wielkiego) i stara się odczytać ich sens. W znaczącym stopniu podpiera swą teorię opracowaną przez siebie analizą nazw własnych, w których w języku Macimowy zapisane jest znaczenie.

Macimowa (Protong w języku angielskim), jak twierdzi Szukalski, jest pradawnym językiem, z którego wywodzą się wszystkie języki ${ }^{12}$. Ma to być w gruncie rzeczy język polski w swojej pierwotnej postaci, pozbawiony gramatyki, złożony z niewielkiej liczby prostych mini-słów (rdzeni, bez przyrostków i przedrostków), które można dowolnie łączyć w niezliczone kombinacje (BP, s. 15, 17, 27). Wszystkie nazwy własne utworzone w Macimowie, jak wyjaśnia Szukalski, odnoszą się do jednego z trzech tematów: 1) Potopu (to słowo oznaczają zbitki la, le, lio, lo, lu, choć czasem słowo to z bojaźni może być skrócone do samego „l”); 2) Ojca i Matki Boga Świtu oraz 3) określenia pochodzenia gór, jezior, ludów ( $B P$, s. 35-36). Jeśli zna się znaczenie słów-rdzeni (ich słownik zamieszcza Szukalski na końcu albumu, $B P$, s. 96), można po „resegmentacji” wyrazu — tego terminu używa Szukalski na określenie analizy słowa, odnajdującej wchodzące w jego skład mini-słowa Macimowy — odczytać jego prawdziwe znaczenie. Przykładowo nazwa jeziora Titikaka, nieopodal którego zachowała się podobizna Wirakocha (szeroko omawiana przez artystę płaskorzeźba z Akkapana, Boliwia), to „Ty Ty! Gdzie Gdzie!” (które należy odczytać jako osobiste i intymne wezwanie do Boga), zaś Wirakocha to „Wiara Kocha” (co należy odczytać jako Ukochany Bóg, BP, s. 49); Gidle, natomiast, miejsce, gdzie Szukalski spędził parę lat swego dzieciństwa, to po resegmentacji „Gi D Le” czyli ,,[Z] Zaginiony Gdzie Powódź” (co należy rozumieć jako wskazanie, że mieszkańcy Gidli przybyli z terenu obecnie zalanego przez Pacyfik, BP, s. 35-36).

Obok Protongu odkrył także Szukalski, jak twierdzi, naukę Piktografii — tj. naukę odczytywania znaczeń obrazków ${ }^{13}$. I tak, na przykład, węże przedstawiają wody Potopu $(B P$, s. 42); ptaki to migracja drogą powietrzną ( $B P$, s. 42$)$; pojedyncza albo podwójna ukośna prosta to „Cięcia Zniweczenia” („Sweeps of Nullification”) — oznaczają śmierć $(B P$, s. 38); orzeł to kapłański posłaniec Boga Świtu (BP, s. 29); smok oznacza ruchy tektoniczne, wypiętrzanie się skał (BP, s. 43, 52). Niektóre rysunki należy odczytywać jak rebusy, odwołujące się do Macimowy, na przykład, otwarte usta to rebus, który należy odczytać jako „Wo La” co oznacza „Zalana Wodą” (BP, s. 39); a drzewo to przypomnie-

${ }^{12}$ Wspomina o tym artysta w cytowanym już liście do Biblioteki w Gidlach. Pisze tam też, że ów „pra-praludzki język” zawiera 74 mini-słowa (inaczej „,półsłówka”) liczące jedną, dwie albo trzy litery (str. 1). Tam też wspomina, że odkrycia Macimowy dokonał podczas drugiej wojny światowej, po wysłuchaniu komunikatu radiowego informującego o tym, że wojska niemieckie wkroczyły na teren Danii. Wiadomość została przekazana z Bohuslany w Szwecji i ta nazwa, jakoby polska, naprowadziła Szukalskiego na trop pradawnego języka (s. 2). Okoliczności, w jakich Szukalski „odkrył” Macimowę pozwalają doszukiwać się związku między trwającą wówczas wojną a pragnieniem odnalezienia ukrytego sensu, może także pradawnej wspólnoty wszystkich narodów, które Macimowa zdaje się wyrażać.

${ }^{13}$ Wspomina tu Szukalski, że opracował stosowny słownik o nazwie „Altheris of Pictography”; $B P$, s. 52. 
nie o Potopie: brzmienie tego słowa w języku Macimowy (tj. „drzewo”) to rebus, poddane resegmentacji przypomina słowa „Gdzie Wody” (BP, s. 41).

Tak więc mamy tu analizę językoznawczą (dokładniej, quasi-analizę morfologiczno-semantyczną nazw własnych), interpretację dzieł sztuki i próbę zrozumienia zjawisk przyrody oraz historycznych zdarzeń, przy czym Szukalski dba o to, by czytelnik rozumiał, jak obserwacja świata skłoniła go do stworzenia teorii Zermatyzmu. Jednocześnie swoje wnioski artysta przedstawia jako bezdyskusyjne, a prawdziwości tez broni twierdząc, że nie ma wykształcenia, a zatem jego umysł nie został skażony schematycznym, tchórzliwym postrzeganiem świata typowym dla uczonych, nie przywykł ulegać autorytetom. Kieruje się natomiast polskim Logosem $(B P$, s. 9) i zdrowym rozsądkiem (BP, s. 11), ma do dyspozycji, jak twierdzi, swoisty ,instynkt rozumienia rzeczy, bez posiadania o nich wiedzy"14 i wrodzoną mądrość, którą zdołał ocalić ${ }^{15}$.

Ponieważ słuszność tez Szukalskiego jest w jego teorii de facto dogmatem, a ich treść jest często irracjonalna, nie sposób Zermatyzmu zaklasyfikować jako teorii naukowej. Jednak ten aspekt metodologiczny, przy całej swej nieporadności, wydaje się wart podkreślenia. Szukalski, starając się uzasadnić swoją metodę prowadzenia badań, wydaje się pokazywać, jak wielkie znaczenie przywiązuje do naukowego statusu swego dzieła. Być może jest to wyraz pragnienia, by teoria, jaką przedstawia, nie była jedynie piękną fantazją, ale adekwatnym opisem rzeczywistości, tj. aby była prawdziwa w znaczeniu odpowiadającym korespondencyjnej definicji prawdy; innymi słowy, by świat był taki, jakim opisuje go Szukalski.

\section{Zermatyzm: kosmogonia, teoria Potopów, Bóg (BP, s. 8-53)}

Wykład Zermatyzmu zaczyna Szukalski od kosmogonii, która pozwala zrozumieć relację łączącą Słońce z planetami, które je otaczają. Słońce jest zarówno ich Stwórcą, jak i cmentarzyskiem, przy czym procesem powstawania i umierania planet rządzą określone prawa, którym podlega także Słońce. Gdy Słońce znajduje się w stanie podwyższonej aktywności, wówczas mimowolnie tworzy planety. Szukalski dwukrotnie przywołuje w tym kontekście obraz garnka pełnego gorącej owsianki, której drobinki pryskają dookoła: tak z gotującej się słonecznej masy wydzielają się komety, które następnie łączą się ze sobą w przestrzeni kosmosu, stygną i stają się planetami (BP, s. 9, 13). Planety to jednakże żywe twory, które oddychają, poruszają się, we wnętrzu których niczym krew krąży lawa. Celem istnienia planet, w tym także Ziemi, jest przywracać życie swemu Stwórcy $(B P$, s. 8). Czynią to oddając mu swój hel i wodór, gdy Słońcu w fazie obniżonej aktywności zaczyna brakować paliwa i energii. Słońce przybliża się wówczas do takiej planety, życie na niej wymiera, a siła ciążenia gorącem (heat gravity, BP, s. 13-14), jaką oddziałuje Słońce, przyciąga wody oceanów i mórz, z których Słońce pozyskuje wspomniane pierwiastki. Gdy zapasy słonecznego paliwa planet, jakie pobrały od Słońca w chwili stworzenia, wyczerpią się ostatecznie, planety umierają. Słońce przyciąga wówczas z ich powierzchni najpierw niezwiązaną materię, a ta, w postaci meteorów i meteorytów, wpada w tarczę Słońca. Na koniec, gdy z planety pozostanie już tylko księżycowe jądro, także ono wpada w Słońce, i tak cykl życia planety zamyka się.

Taki kształt relacji między Słońcem i planetami determinuje przebieg zjawisk klimatycznych na Ziemi i, tym samym, ludzkie życie. Zmiennej aktywności słońca odpo-

14 ,instinct for UNDERSTANDING things, without knowing what they were”, $B P$, s. 14.

$15,,[\ldots .$.$] Wisdom all humans are born with, my inner capacity to solve the dilemmas that$ previous scientists failed to budge", $B P$, s. 18 . 
wiadają bowiem w życiu planety Epoki Blisko- i Dalekosłońca ${ }^{16}$, a każda z nich wywołuje inny charakterystyczny typ potopu. W Epoce Bliskosłońcej nadyma się zbudowane z lawy dno oceanów i mórz (tzw. Glob Wtórny, the Secondary (lavaic) Globe) i to wydęcie powoduje wystąpienie wód i zalanie powierzchni Pierwotnego Globu. W Epoce Dalekosłońcej wulkaniczne kontynenty, które wynurzyły się w poprzedniej epoce, zapadają się i zanurzają pod wodą, wynurza się natomiast glob pierwotny (the Primary (geologic) Globe, BP, s. 10). Cykl falowania dna morskiego odpowiada cyklowi aktywności i położenia Słońca i trwa 26000 lat. Potop to kluczowe zdarzenie w historii ludzkości, a dokładniej „największy kataklizm jakiego doświadczyła”17. Uratowali się tylko nieliczni, którzy zdołali uciec z zatopionej Wyspy Wielkanocnej i dopłynąć do suchego lądu. Swoje schronienie znaleźli w górach: Alpach i Pirenejach (BP, s. 29), między innymi część z nich dotarła szczęśliwie do położonego w Alpach szwajcarskich Zermatt ${ }^{18}$ (skąd też wywodzi się nazwa całej teorii Szukalskiego) ${ }^{19}$.

Potop wyrządził także szkody bogom. W wyniku Potopu zalani zostali Matka i Ojciec, ,żona” i „mąż” (te dwa określenia stosuje Szukalski z cudzysłowem), inaczej Wyspa Wielkanocna na Pacyfiku i Oce On na Atlantyku. Ta Bogini topielica i Bóg topielec, jak można by powiedzieć, przebywają od tego czasu w głębinach wód, czy też krainie, do której trafiają zmarli (in the Netherworld, BP, s. 45). Przy życiu pozostaje ich Syn: Świt/Zorza/Słońce. Codziennie rodzi go zatopiona Matka, następnie Syn pełznie po dnie Oceanu Spokojnego i dalej po dnie Atlantyku, gdzie na swoich ramionach wynosi go ponad powierzchnię wód zatopiony Ojciec, zwany w tym kontekście Krzysztofem (BP, s. 40-41). Syn co dzień rodzi się o świcie i umiera o zmroku, ale kiedy nadejdzie Epoka Bliskosłońca, uwolni zatopionych rodziców.

Każdą z tych trzech postaci, Matkę, Ojca i Syna, można odnaleźć, zdaniem Szukalskiego, we wszystkich religiach $(B P, \text { s. } 48)^{20}$. Każdą też z nich Szukalski szczegółowo omawia. Matka, „matczyzna”21 wiąże się geograficznie z Wyspą Wielkanocną ${ }^{22}$, jej godłem jest lwica, ona sama jest zaś przedstawiana jako syrena albo kobieta — najczęściej łysa, pozbawiona piersi, często także stóp. Atrybuty te mają swoje znaczenie: „łysa” odczytać należy jako rebus zapisany w Macimowie: „Li Ze” czyli Zalana Ziemia

\footnotetext{
${ }^{16}$ Lameński przyjmuje inne tłumaczenie terminów Farsolar i Nearsolar: Do-słoneczny i Od-słoneczny (L. Lameński, Stach z Warty Szukalski, s. 233), pozostanę jednak przy terminach, którymi posługuje się sam autor w liście skierowanym do Biblioteki w Gidlach, s. 2.

17 ,the greatest cataclysm mankind experienced”, $B P$, s. 22.

18 "Zermatt, po resegmentacji „Zer Matt”, oznacza Matka Zorzy/Świtu i upamiętnia Wyspę Wielkanocną. Stąd wywodzi się nazwa „Sarmaci”: to ludy, które opuściły Zermatt i przybyły na tereny Polski w poszukiwaniu ziemi uprawnej; $B P$, s. 30.

${ }^{19}$ Ludzie często ratowali się płynąc wpław. Jako że w epoce Dalekosłońcej wody mórz były błotniste, ich twarze, gdy wynurzali się na brzeg, pokryte były zaschniętą warstwą błota, co widać na licznych rysunkach i rzeźbach pochodzących z tamtych czasów, jak twierdzi Szukalski. Na podstawie wzoru, jaki tworzyło błoto, można rozpoznać styl pływaka. W późniejszych czasach wzory te utrwaliły się jako oznaczenie przynależności plemiennej (w języku angielskim „tribal flood scumlines”). To zagadnienie omawia autor niezwykle szczegółowo, $B P$, s. 19-26.

${ }_{20}$ „All religions have been encrusted around three personalities, the Mother(land), the Father(land) and their hoped-for Saviour, the Dawn (who, when the Nearsolar Epoch comes, will actually save them from their present submersion)", $B P$, s. 48.

${ }^{21}$ Tego słowa używa Szukalski w liście do Biblioteki w Gidlach, pisząc o swojej teorii (s. 2). W albumie w języku angielskim używa słowa „motherland”, które na język polski przekłada się zazwyczaj jako ojczyzna.

${ }^{22}$ Wyspa Wielkanocna ma jeszcze dwie inne nazwy; obie - Rapa Nui, po resegmentacji w języku Macimowy „Ra Ba Nu Je”, i Mata Weri - oznaczają Matkę Boga Świtu, BP, s. 19, 36.
} 
$(B P$, s. 27); brak piersi oznacza dziewictwo (BP, s. 29, choć kiedy indziej może też oznaczać starość, $B P$, s. 31) brak stóp - niemożność ucieczki przed Potopem ( $B P$, s. 28). Przykładem zachowanych przedstawień Matki są figurka Matki Boskiej Gidelskiej, obraz Matki Boskiej Częstochowskiej (obie pokazują zarazem związek Matki z nowotestamentową Matką Jezusa), czy brytyjskie figurki Sheila-na-Gig ${ }^{23}$ (podobizna jednej z nich została umieszczona z przodu na okładce albumu). Ojciec, Oce On (czyli „On z Ojców” w Macimowie BP, s. 41), to także zatopiony kontynent (choć nazwa może błędnie sugerować, że tym razem chodzi o ocean). Godłem jego jest żółw wodny. Babilończycy czcili go jako Ea, Izraelici jako Jahwe, chrześcijanie jako Boga Ojca (BP, s. 41). Syn (Świt, Słońce, Zbawca) to także Jezus („Je Z Us” po resegmentacji w Macimowie imię to znaczy „Jest z śmiertelnie Uśpionych”, tj. z Wyspy Wielkanocnej, BP, s. 40); dokładniej, Jezus to późniejsza reinkarnacja Boga Świtu (BP, s. 28); a śmierć Syna, zatonięcie, to to samo co ukrzyżowanie ${ }^{24}(B P$, s. 28,42$)$. Jednak Syn to nie tylko Jezus, ma on wiele innych reprezentacji, jest także, na przykład, starotestamentowym Baalem, którego imię oznacza Wschód Słońca (BP, s. 42).

Gdy nadeszła powódź, Bóg Słońce nie zdołał uratować ani swoich rodziców, ani modlących się o ratunek ludzi, chociaż liczne artefakty przedstawiają Boga (albo Boskich rodziców) walczących z Wężami Potopu ${ }^{25}$. Prawa Religii, jak wyjaśnia Szukalski, znalazły się w konflikcie z prawami Międzyplanetarnymi. Ponieważ Słońce wyczerpało swoje paliwo, siła słonecznego oddziaływania za pomocą grawitacji cieplnej na satelity Słońca osłabła, skutkiem czego oddaliły się one w przestrzeń i pokryły szronem, zwiastując początek Epoki Dalekosłońcej ${ }^{26}$. Wyspa Wielkanocna i Oce On, jako kontynenty wulkaniczne (część globu wtórnego, BP, s. 41), znalazły się wówczas pod wodą.

\section{Zermatyzm: antropologia, teoria Małpoludów (BP, s. 54-81)}

Wprowadzając tematykę antropologiczną, Szukalski wyjaśnia, że wobec dwóch wojen światowych nie sposób nie zadać pytania o przyczyny tych nieszczęść. Jest nią, jego zdaniem, walka między ludźmi i nieludźmi ${ }^{27}$, z której wszakże nie zdajemy sobie sprawy, biorąc Małpoludy za ludzi. Tymczasem Małpoludy, zwane też przez Szukalskiego inaczej Yetinsynami i Yetidochami, zależnie od płci, to potomstwo ze związków

${ }^{23}$ Te figurki, podobne do „Polskich Bab” (znalezionych na stanowiskach archeologicznych w Polsce figurek, które przedstawiają postaci kobiece łyse i bez piersi), spotykane są na całym świecie i najczęściej przedstawiają kobietę w pozycji rodzącej w kucki. Imię „Sheila-na-Gig” autor resegmentuje jako „Zi (J)e La Na Gi G(e)”, co oznacza „Ziemia (która) Jest Zatopiona, Rodząca Zginęła, Zalana", $B P$, s. 33.

${ }^{24}$ Trudno jednak powiedzieć, czy to utożsamienie śmierci przez utonięcie z ukrzyżowaniem wystarcza, by mówić o ofierze Boga u Szukalskiego.

${ }^{25}$ Omawiając jeden z artefaktów przedstawiających Boga, egipską płaskorzeźbę przedstawiającą Boga Ra, Szukalski odnotowuje, że ręce Boga są wolne (laskę ma zatkniętą za pas) „,by mógł uchwycić Węże Potopu i uratować świat” („For the daily journey, he has a cane stuck in his belt leaving his hands free for the grasping of the Flood Serpents in order to save the world"; $B P$, s. 45).

26, ,[...] fewer and fewer pilgrims arrived, till all life had vanished from the surface of the Atlantic Ocean, and none of the pleading cities and isles remained to seek salvation, for the Divine Sun had other than the Laws of Religion to obey, which were INTERPLANETARY. The Sun needed reimbursing of its combustive elements which were spent by then and the satellites were released from its decreasing heat-gravity and sent into the vaster interplanetary spaces to be covered with hoarfrosts in the then-ensuing Ice Ages"; BP, s. 49.

${ }^{27} \mathrm{~W}$ oryginale Humans i a-Humans (BP, s. 55), Manapes (BP, s. 59), Yetinsyny, czyli synowie Yeti, i Yetidochy, czyli po rosyjsku [sic!], córki Yeti (BP, s. 61). 
mieszanych, ludzi i małp. Po części winne istnienia tego potomstwa są małpy, które w odległej przeszłości atakowały i gwałciły kobiety, po części winni są mężczyźni, którzy współżyli z samicami antropoidów. Małpoludy udają, że są ludźmi, podstępnie wykorzystując ludzkie dobre serce i łatwowierność. Można je jednak rozpoznać dzięki ich szczególnej fizjonomii. Małpoludy charakteryzuje m.in. potężny brzuch, krótkie ręce, często schowany ogon, zwały skóry na karku i niemal całkowity brak szyi. Ich twarze mają masywne rysy, w szczególności duży odstęp między nosem a górną wargą, a mały między oczami i nosem, wypukłe łuki brwiowe, nosy przypominające brodawki. Typowe cechy psychiczne Małpoludów to chciwość, zawiść i drapieżność. Często cierpią na kompleks niższości i bywają niepełnosprawne umysłowo, choć większość z nich umie posługiwać się językiem. Ich nienawiść do ludzi jest wynikiem odrzucenia: $\mathrm{z}$ racji odpychającego wyglądu Małpoludy nie są w stanie znaleźć dla siebie partnerów seksualnych wśród pięknych ludzi, których kochają; dlatego pragną ich zniszczyćc ${ }^{28}$. Ostatecznie jednak to nie szlachetni ludzie i nie podłe Yetinsyny czy Yetidochy wybierają, jak chcieliby żyć: jedni i drudzy są bowiem zasadniczo zdeterminowani genetycznie $^{29}$. Warto jednocześnie zauważyć, że imperia, które Małpoludy potrafią tworzyć, sprzyjają rozwojowi nauki i kultury, że Małpoludy mają dużą wyobraźnię (skutek ciągłego marzenia o pięknych partnerach), niewyczerpaną cierpliwość i zwierzęcą żywotność. Właściwe postępowanie z Małpoludami polegałoby na tym, by zachęcić je do twórczości artystycznej albo pracy w takich dziedzinach jak medycyna czy inżynieria; mogą wówczas przynieść ludzkości pożytek (BP, s. 63; w innym miejscu pisze jednak Szukalski, że Małpoludy, w każdym razie te $\mathrm{z}$ nich, które zabijają ludzi, należy uśmiercić i to bez procesu sądowego ${ }^{30}$ ). Jako przykłady znanych z historii świata Yetinsynów i Yetidoch, Szukalski wymienia Robespierre'a, Trockiego, Dantona, Carycę Katarzynę, Królową Wiktorię, Churchilla, Chruszczowa, Kropotkina i Bakunina, Sokratesa i Nietzsche-

${ }^{28}$ Poniżej ustęp, w którym Szukalski szczegółowo omawia naturę małpoludów: ,[...] as frightfully inferiority-obsessed males and females who NEVER get beautiful women and men into their beds, they persistently dream of the IMPOSSIBLE. To endure their mental hardships they develop extraordinary patience and such perfect IMAGINATION that almost anything they dream of, they are capable of contriving. Thus, patience and imagination, together with their ANIMAL vitality, make them capable to contribute miracles of invention in every sphere of interest. [...] Politically, they forever remain ... socialists and therefore, potential communists, because they cannot forgive humankind its popularity with the opposite sex. Humans love and are loved. Yetinsyny love human women and men, but are never loved in return by them. In the formative years of their adolescence that decides for the rest of their lives their hatred of mankind in general from the bottom of their feel's soles. They NEVER forget and NEVER forgive. But if their hope for vengeance is sublimated into beneficial inventiveness, and from their frantic industriousness and total dedication to their skills they get the reward - sincere gratitude, appreciation and fame, which is LOVE - from mankind, they purr like kittens and become the best of friends of appreciative humanity that is ALWAYS NOBLE”; $B P$, s. 63.

${ }^{29}$ „Though we may insist on preserving our inalienable Right of Freedom in America, we can never alter the biological heritage each of us has at birth, which preordains us to fulfill our specific Mission. [...] Due to the combination of our parents' physical and mental traits and our total CHANCE conception [...] you and I are the inheritors of a personality that may go back to millions of years ago and that could have been some almost divinity or the basest of criminals"; $B P$, s. $74-75$.

30 „Do we reproach a wolf, a hyena if it kills? Do we think them criminal? If a dog with rabies attacks a child, we do not sue in court, but simply kill the offender. The semi-Humans who kill-kill-kill are not criminals, they are dangerous animals, and Justice with human consideration does not apply to them. They simply should be eliminated without the process of law, being an economic burden on human society as it is"; $B P$, s. 71. 
go. Małpoludy są najgroźniejsze jako twórcy ideologii, politycy i władcy, którzy wywołują wojny i rewolucje, ale mogą też wywoływać epidemie, przenosząc odzwierzęce choroby; te ich działania w konsekwencji mogą doprowadzić do upadku cywilizacji.

\section{Interpretacja Zermatyzmu - wyjaśnienie cierpienia i zła}

Tak oto przedstawia się skrócony wykład teorii Zermatyzmu, na jaki mógł sobie pozwolić Szukalski w liczącym zaledwie 96 stron albumie Behold!!! The Protong ${ }^{31}$. Centralnym problemem, który autor stara się poprzez swoją teorię rozwiązać, wydaje się być ludzkie cierpienie, które postrzegane jest jako zło. Otóż z teorii Szukalskiego wynika, że cierpienie, jakiego doświadczamy w wyniku kataklizmów (takich jak na przykład potop), jest nieuniknionym wynikiem praw fizyki, które rządzą ruchem planet i Słońca. Bóg (Słońce) podlega im i, jeśli ludzkie modlitwy wchodzą z tymi prawami w konflikt, jest bezsilny, nie może ich wysłuchać. Obraz świata Szukalskiego jest teocentryczny; człowiek i inne żywe istoty są tu raczej bytami przygodnymi, daleko ważniejsze są zaś ciała niebieskie: Słońce i planety, które ze Słońca powstają, wokół Słońca krążą, Słońcu oddają najpierw swoje zapasy słonecznego paliwa, potem siebie, to bowiem jest ostatecznym celem ich istnienia. W jakimś sensie także człowiek (mieszkaniec planety) uczestniczy tym samym w życiu Boga. Zarazem Bóg nie jest jedynie odległym ciałem niebieskim, ale i częścią świata: Boży Ojciec i Matka to zalane wodą kontynenty naszego globu, a sam Bóg każdego dnia z rana rodzi się w głębinach, trudzi się mozolnie pełznąc po dnie oceanu i wieczorem umiera, zanurzając się z powrotem w jego odmętach, czasem udziela pomocy (walczy z wodami Potopu, obdarza ciepłem i jasnością świat, kiedyś ocali swoich rodziców), innym razem sam jej potrzebuje (np. gdy Ojciec wynosi Słońce nad powierzchnię oceanu). Taki obraz Boga może wzbudzać ufność: Bóg jest potężny, ale zarazem podobny do człowieka; wykracza poza jego świat, ale i do niego należy; kiedy może, stara się nieść pomoc.

Jednak, jakby w opozycji do takiego obrazu Boga, pojawiają się w albumie między wierszami uwagi, które zdają się wyrażać dystans wobec Boga, na przykład zdanie „Tylko ten, kto kocha te TWORY (z którymi żaden Bóg nie mógłby się równać) umiałby je narysować $\mathrm{z}$ takim oddaniem jak ja" (mowa tu o rzeźbionych figurkach) ${ }^{32}$ albo wzmianka o tym, że opatrzność stoi po stronie pisklęcia kukułki, które zaraz po wykluciu, wyrzuca pozostałe pisklaki z gniazda ${ }^{33}$. Także $w$ niezwiązanym już z Zermatyzmem eseju Society or Public, który wchodzi w skład albumu, pojawia się, i to explicite, wątek zbędnego Boga. Pisze tu Szukalski, że już jako dziecko nie odczuwał potrzeby Boga: „Gdy byłem chłopcem, Bóg nie był mi do niczego potrzebny. Już wtedy czułem, że Bóg był dla innych ludzi, ja natomiast byłem samowystarczalny, zupełny, bez

${ }^{31}$ Wielokrotnie wyraża Szukalski ubolewanie z powodu braku możliwości pełnego przedstawienia swoich odkryć (por.: „The prescribed size of this book makes it possible only that I blurt out short gushes of breath as a call for help"; BP, s. 19).

32 „Only one who loves these CREATIONS (that no God could ever match) would draw them as lovingly as I do"; $B P$, s. 23.

33 „The young cuckoo is born glistening-skinned nude, looking like a reptile. Immediately it lays on its back and begins to push the legitimate pippit children out of the nest. The expulsions of the nestlings, which are minuscule in comparison to the parasitic invader, is so gruesome and sickening a sight, that I barely was able to continue watching the documentaries in which this was shown. But if you would see nature at its worst and take the lesson of whose side Providence stands on, do not miss the opportunity"; BP, s. 62 . 
przechwałek, zupełny"34 i, chociaż jako dziewięciolatek służył do mszy u dominikanów, wkrótce potem przestał interesować się religią. Dalej twierdzi Szukalski, że miejsce Boga zajęła w jego życiu Polska ${ }^{35}$, a swoją duszę, stając się artystą, stworzył dla siebie sam $^{36}$. Kiedy natomiast jako zapoznany artysta ,tygodniami w milczeniu znosił głód, nie miał do kogo zwrócić się o pomoc, nie miał ojca, króla, prezydenta ani

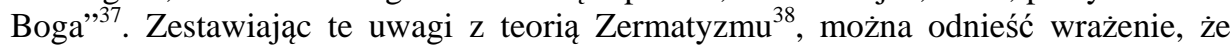
autor nie do końca rozumiał znaczenie sztuki (albo nauki), którą tworzył, trudno bowiem nie zauważyć, że teoria ta dotyczy Boga, jest próbą wskazania Bożej obecności w życiu człowieka i Bożej bezradności wobec ludzkiego cierpienia, co zarazem pozwala, jak się wydaje, zachować wiarę w dobroć Boga ${ }^{39}$.

Inny rodzaj zła — wojny, zbrodnicze ideologie, epidemie i choroby, które także wyniszczają ludzkość i niosą cierpienie — to wynik działań małp i Małpoludów. Pierwotnie zawiniły małpy, które gwałciły kobiety, i mężczyźni, którzy współżyli z małpami (jeśli chwilowo pominąć teorię genetycznego determinizmu). Człowiek nie jest zatem bez winy, ale wina ta polega na braku wstrzemięźliwości we współżyciu seksualnym (i nadmiernej łatwowierności), nie zaś na pragnieniu czyjejś krzywdy. Głównymi sprawcami zła są natomiast małpy i Małpoludy (tj. zwierzęta, które trudno jest winić o złe zamiary, wobec ich ograniczonej świadomości moralnej). Przyczyną, dla której te ostatnie pragną zniszczyć ludzkość, jest zawiść istot, których miłość została odtrącona, których nikt nie pokochał. Złośliwy charakter Małpoludów, jak charakter wszystkich istot, jest jednocześnie zdeterminowany przez materiał genetyczny, co można odczytać jako drugą już próbę usprawiedliwienia ich działań. Obecnie żyjące Małpoludy zachowują się zgodnie z tym, jakie odziedziczyły geny po swoich przodkach — to zaś jest wynikiem całej historii świata, sięgającej wstecz jeszcze przed czasy Potopu. Cierpienie wpisane jest w nasz świat. Wynika ono jednak z zawiści Małpoludów (na którą Małpoludy są genetycznie skazane), nie zaś z ludzkiej nienawiści czy złości.

W świecie Szukalskiego istnieje zatem dobry Bóg i ludzie, którzy są szlachetni, dobrzy i piękni ${ }^{40}$. Nawet o Małpoludach można powiedzieć wiele dobrego — są twór-

${ }^{34}$ „As a boy I had no use or need of God. I, even then, felt that God was for everyone else, but I was self-contained, complete, unboastfully complete"; $B P$, s. 91.

35 „I had no time for God, for his place was taken by the mere word «Poland» [...]”; BP, s. 91.

36 „I have actually made myself a SOUL, by making myself a CREATIVE artist”; $B P$, s. 93.

37, ,[... I was starving for weeks at a time in silence, having no father, king, president or God to turn to with my personal complaints"; $B P$, s. 94.

${ }^{38}$ Wydaje mi się, że takie zestawienie, które zakłada możliwość utożsamienia w obrębie albumu Boga tradycyjnego teizmu z Bogiem Zermatyzmu, jest uprawnione: czy w dyskursie dosłownym, czy artystycznym mowa jest o tym samym Absolucie.

${ }^{39}$ Podobne wrażenie niespójności można odnieść czytając opowiadanie Szukalskiego Niemy Śpiewak; zob.: S. Szukalski, Niemy Śpiewak. The Mute Singer, tłum. K. Jaskuła, Lublin 2010. Opowiadanie wyraźnie demaskuje niedostatki ludowej pobożności, przeciwstawiając jej mistyczne doświadczenie obecności Boga w świecie. Tymczasem w albumie Behold!!! The Protong Szukalski utrzymuje, że opowiadanie, będące częścią jego autobiografii, dowodzi właśnie, iż nigdy nie potrzebował Boga $(B P$, s. 91). Interpretację religijnych treści tego opowiadania przedstawiam w dwóch esejach: J. K. Teske, Żaby, żebracy i Bóg: pojęcie cudu w opowiadaniu Stanistawa Szukalskiego „Niemy Śpiewak”, Archiwum Emigracji. Studia - Szkice - Dokumenty 2011 z. 1-2 (14-15), s. 336-341; taż, „,Niemy Śpiewak” Stanistawa Szukalskiego: portret autora, człowieka czy Boga?, Akcent 2011 z. 1(123), s. 178-181.

${ }^{40} \mathrm{~W}$ powyższej prezentacji te przymioty ludzi nie wysuwają się na pierwszy plan. Można je jednak odnaleźć w albumie pośrednio w opisach Małpoludów, do których ludzie nie są podobni, 
cze, pracowite, mają bogatą wyobraźnię, choć nie zmienia to faktu, że sieją wokół siebie zniszczenie. Świat uczestniczy w życiu Boga (jak inne planety położone wokół Słońca) i u kresu swego istnienia znów się ze Słońcem połączy. Cała ta wiedza o Bogu, o człowieku, o świecie, o źródłach cierpienia jest człowiekowi dostępna: zapisana jest w nazwach własnych, w artefaktach, w zjawiskach przyrody. Nie każdy potrafi sam je rozpoznać; w razie potrzeby Szukalski gotów był spieszyć z pomocą, żarliwie bowiem pragnął upowszechnić swoje odkrycia ${ }^{41}$. Fakt, że wytwór swojej fantazji artysta przyjął za rzetelny, naukowy opis faktycznie istniejącego świata, to chyba największa usterka całego dzieła, jeśli oceniać je krytycznie. Zermatyzm, świadectwo niezwykłej wyobraźni i talentu plastycznego, staje się przez tę usterkę dość dramatycznym wyrazem pragnienia, by wierzyć w dobro w czasach, gdy miliony ludzi poniosły śmierć w wyniku bratobójczych wojen, przed którymi nie uchroniła ich żadna ponadnaturalna moc. Dla kogoś o wrażliwej duszy i niestabilnej psychice taki świat mógł być nie do przyjęcia. Może dzięki takiej niezgodzie na zło czytelnik Szukalskiego może teraz czytać o Macimowie, Potopie, wzdymającym się dnie oceanu, Słońcu jak garnek owsianki, smutnych i zawistnych Małpoludach, o bardzo dziwnym świecie, który był wszakże wolny od Bożej obojętności i ludzkiej podłości.

\section{"BEHOLD!!! THE PROTONG"-THE FLOOD AND APE-MEN, THE THEODICY OF STANISŁAW SZUKALSKI}

The essay is devoted to the original theory of Zermatism developed by Stanisław Szukalski between 1940 and 1987, and presented to the public in fragments in the album Behold!!! The Protong (1980). Though intended as a work of science, the theory may be interpreted as a work of art, whose leading theme is theodicy: an attempt to defend God's goodness (and, additionally, man's nobility) in the face of evil. In Szukalski's theory, suffering either is a side-effect of Interplanetary Laws, against which God (the Sun) is powerless, or results from hostile actions of ugly Manapes, whose malice against beautiful mankind reflects their sorrowful alienation. Suffering, therefore, does not imply either God's indifference or human wickedness. Szukalski's insistence that his work should be taken as scientific rather than artistic might indicate the artist's desire for his vision to be true.

KEY WORDS: Stanisław Szukalski; Protong; Zermatism; God, theodicy.

albo między wierszami, w takich ustępach jak poniżej przytoczony. Omawiając Tonatiuh (płaskorzeźbę przedstawiającą aztecki kalendarz), Szukalski opisuje tu dwie postaci ludzkie, których płci nie sposób rozpoznać, ponieważ, jak wyjaśnia, Aztekowie nie potrafili pokazać inaczej kobiety i mężczyzny, nie znając sposobu, by przedstawić Czułość i Miłość (z czego wydaje się wynikać, że to te dwie cechy są konstytutywne dla kobiecości i męskości): „That there is no indication in the faces as to which one is man and which one woman, is due to the fact that Aztecs did not know how to make a woman's face different from that of a male. They never conveyed Tenderness or Love, hence knew not femininity or gentility"; BP, s. 52.

${ }^{41}$ Dwuznaczne wydaje się w tym kontekście sformułowanie, które pojawia się w albumie jako swoiste rozwinięcie nazwy Zermatyzm: „I CLAIM THIS WORLD” (BP, s. 49) — „TO JEST MÓJ ŚWIAT”, które zdaje się w zaborczy sposób podkreślać prawo własności autora. 